\title{
The sleep of reason and of imagination produces monsters
}

\author{
An Editorial Introduction
}

\author{
Cristina Beretta*
}

Inspired by Francisco Goya's most famous etching, El sueño de la razón produce monstruos (1797-99), in its interpretation as 'The Sleep of Reason Produces Monsters', we decided to dedicate the 2019 special issue of Colloquium: New Philologies to the topic of nationalism. To this purpose, we organized the annual $3^{\text {rd }}$ AARC PhD Students' Conference entitled Language.Literature.Politics. 1918-2018. (Un)doing Nationalism and Resistance, with the support of the Alpen-Adria-Universität Klagenfurt and under the patronage of the Alps-Adriatic-Rectors' Conference (AARC), to gather researchers on various academic levels not only from the Alps-Adriatic region but also from all over the world, to reflect upon the topic. The articles of this issue of Colloquium: New Philologies are a selection of the papers of this conference, which took place between $20^{\text {th }}$ and $22^{\text {nd }}$ September 2018 at the Alpen-Adria-Universität Klagenfurt/Celovec, Austria in the wake of the commemorative year of the end of World War I.

In fact, the world shortly after 1918 seems very similar in many ways to the state of affairs one hundred years later, as another major push against multinationalism, multiculturalism, and globalism is clearly evident. Mirroring 1918 and the nationalist movements of the time, the second decade of the $21^{\text {st }}$ century seems to have brought a strong (or at least a loud) return to nationalism, thus evoking the impression of an eternal recurrence of things. After a long general movement into globalization, unification, and multiculturalism that has marked the period succeeding World War II, nationalism, particularly in the Western World, seems more pronounced today than any time in the last 70 years, and it is particularly rampant in the political discourse of today. Paradoxically,

\footnotetext{
* Institut für Slawistik, Alpen-Adria-Universität Klagenfurt; cristina.beretta@aau.at
} 
supranational entities such as the EU, seem to be deriving new motivation precisely from the revival of these nationalistic movements. Thus, these contrasting tendencies require a thorough look into the languages not only of nationalisms, but also of critique and resistance to them, especially into their narrative, rhetoric, and argumentative strategies, as well as their use of metaphors, images, and other devices of communication. This was the aim of the conference.

Its peculiar and at the same time typically European history makes the Alps-Adriatic region an inspiring starting point for the conference. This border region at the intersection of three linguistic areas, the Germanic, the Slavic and the Romanic languages, constitutes something unique within the European region. It was one of the major front lines of World War I, which brought along the end of two empires, the Habsburg and the Ottoman one, not only fostering substantial political, social and economic changes but also introducing new state borders in the area. Plagued by Nazism and Fascism and the resulting World War II, the area had to witness within its larger borders the Yugoslav civil wars of the 1990s, which again brought along new borders and nation-states. Thus, the region itself represents an 'ideal' case study for thinking about nationalism. At the same time, the conference aimed to extend its scope beyond the Alps-Adriatic borders. A productive reflection on nationalism cannot be confined to a single region but requires instead a broader approach that transcends European culture(s), including postcommunist experiences, so as to incorporate global as well as post-colonial reflections in order to facilitate a comparison and a mutual stimulation of reflections. The conference hosted researchers from universities of about fifteen countries in and outside Europe from the fields of linguistics, literary studies and cultural studies. The participants considered a variety of issues related to the central theme of the conference, i.e. the various ways in which nationalisms are being articulated, negotiated, challenged, and played out in various cultural forms of expression, from literary texts to political rhetoric, and from language policy to the discourses of religion, fashion and advertisement.

The selected papers gathered in this issue were written by scholars of all stages, displaying different approaches from diverse scientific traditions. The first section, Nationalism and Resistance, focuses on the multifaceted ways literature addresses the possibility of questioning, resisting and fighting nationalism. The second section, Language of Nationalism, turns to analysing the devices, strategies and methods of nationalistic language, and contains suggestions on how to oppose these strategies.

A philosophical-theoretical contribution by Alice Pechriggl (University of Klagenfurt/Austria) frames the first section Nationalism and Resistance. In her contribution, in which she also draws on psychoanalysis and political science reaching back to Greek 
antiquity, Pechriggl analyses nationalism as the regressive acting out of affects against an imagined Other, which occurs on the basis of a friend-foe-logic as well as the identitarian phantasms of collective sameness denying the peculiar quality of each nation, which is in fact diversity. She also interrogates the phantasm of language purity, which makes nationalism incapable of integrating differences, and the nationalistic incapability to regard conflicts as something negotiable. As a response, she envisions radical democratic action on the basis of deliberative action that sees conflicts as something negotiable.

The first two papers are from the field of literary studies. Matija Bošnjak (University of Sarajevo/Bosnia and Herzegovina) shows how the novel Noćno Vijeće (The Night Council) by one of the most prolific contemporary Bosnian authors, Đževad Karahasan, challenges the modern notion of rationality as the founding principle of modernity. At the same time, the novel questions nationalism along with other systems of beliefs (communism, capitalism) as adequate foundations of society, while recognizing compassion as a at least one adequate ethical principle. Among other sources in literary studies, Bošnjak explores the criminal novel as well as Plato's neglected dialogue The Laws.

Drawing on plenty of theoretical studies on post-nationalism, Ali Dahdaridad (University of Rome/Italy) illustrates how literature can help delegitimize the hegemony of nationness by focusing on the novels Mason E'Dixon and Against the Day by the American post-modernist writer Thomas Pynchon. By means of suggesting and creating alternative, parallel realities to the nationalized world, which do not refuse the reality of nations themselves, both novels mobilize a counter-hegemonic postnational imagination, which questions the hegemonic national ideology as the sole force that can arrange and organize the world.

Nataša Tučev (University of Niš/Serbia) begins her reflection in the field of literary studies on James Joyce's critique of nationalism by pointing out that, although supporting Irish anti-colonial liberation movement against British imperialism, he considered any form of nationalism as a ruinous "prescriptive myth" of identity. This critique also informs Ulysses, where nationalistic ideology is mocked and depicted as narrow-minded and absurd, while the text proposes an alternative of resistance to it: interest for and will to acknowledge the Other, multi-perspectivity ("parallax") and erotic love as a way of embracing humanity.

In his literary study paper on Turkey's postmodern historical fiction, Bariş Yilmaz (University of Szeged/Hungary) underlines how various novels, such as by successful and well-read authors like İhsan Oktay Anar, Nedim Gürsel, Hasan Ali Toptaş, Ömer Zülfü Livaneli, subvert mechanisms of power by retelling historical events from the counterposition of those whose who are denied representation in official historical narratives. He investigates the novel's self-reflexive consideration on the thin line dividing 
facts and fiction, historical and imaginative writing, and addresses the crucial question of the function of (postmodern) literature as an alternative to authoritarian, nationalistic discourses, while criticizing the role of historiography which often serves to supply those discourses with alleged historic evidence.

Tomas Cenys's (Vilnius University/Lithuania) literary study paper opens the second section of this issue, Language of Nationalism. Cenys investigates Viktor Pelevin's postmodernist novel S.N.U.F.F. as a reflection on mechanisms of propaganda, such as the use of extremes, novelty and the mysterious to produce tension and captivate the public's attention by appealing to the emotions and the irrational. By underlining the analogy with the mechanisms of political influence of the Baroque period, the paper establishes a troubling connection between the Counter-Reformation's propaganda fidei of the $17^{\text {th }}$ century and current Russian ideological indoctrination and psychological manipulation through mass media and cultural production.

Petra Hesse's (University of Klagenfurt/Austria) literary study paper focuses on two major Russian dystopian novels of the $20^{\text {th }}$ century: Evgenij Zamjatin's We and Tatjana Tolstaja's Kys, the first being a warning of (Socialist) totalitarianism as an exclusively rationality-based replacement for irrational ambitions, such as antagonism between classes and nations; the latter depicting a return of a violent, primitive and xenophobic irrationalism. Hesse shows how both novels unmask the devastating social effects of reductionism: Zamjatin's novel by depicting an absolute technocratic rationality turning individuals into mathematically functioning machines, Tolstaja's novel by investigating the complete abandonment of rationality which leaves the individuals without any moral, legal or cultural frames.

The contribution by Anela Mulahmetović Ibrišimovićand Nerma Pezerović-Riđić (both University of Tuzla/Bosnia and Herzegovina) investigates the application of conceptual integration theory to analysing the cognitive mechanisms behind the potential impact of social issue advertisements. Through this prism, this contribution looks at three instances of advertisements that promote the critique of and reflection on racism, sexism, and indifference. Thus, it indirectly raises the question of how the insights generated by this theory can be used to produce social issue advertisements to criticize other mechanisms of exclusion, including divisive nationalism.

Based on historical discourse analysis, Sarah Ritt's (University of Vienna/Austria) communication studies paper presents the results of investigating the representation of Northern Ireland's prevailing opposite nationalisms, unionism and republicanism. Her paper reveals that both receive low-level coverage in selected widely-read Northern Irish newspapers in a two weeks-span on the occasion of the Good Friday Agreement's anniversary in 2018. 
Tena Šinjori's (University Zagreb/Croatia) sociolinguistic paper investigates the way the migration processes to the European Union between 2011 and 2018 inscribed themselves into Czech language by analysing the most expressive linguistic responses to contemporary social changes, i.e. neologisms. Since new lexical elements arise in a language not only to name new phenomena, but also to express new affective nuances of already stable lexical items as well as to reflect specific circumstances, they reveal the speakers' attitudes toward contemporary issues. Šinjori shows how Czech neologisms concerning migration display a rather negative, xenophobic, binary attitude toward migration.

Manuel Theophil's (University of Koblenz Landau/Germany) literary study paper considers how the 1930s novels of German author Klaus Mann reflect on the notion of Ungleichzeitigkeit ('contemporaneousness'), as coined by Ernst Bloch in order to explain Nazism. Bloch describes Nazism as capitalising on Ungleichzeitigkeit on various levels, thus getting hold of the desires of the people, especially the primitive, utopian dream of a salvator mundi or a paradise-like society. Theophil shows how Mann exposes the fatal Ungleichzeitigkeit of various social groups which all fail to grasp the real scope of Nazism. He concludes with a glimpse into contemporary German literature and the function that Bloch's notion could have to push back present nationalistic antidemocratic movements.

Elisa Vitali (University of Milano/Italy) investigates the mainstream national identity discourse in contemporary Japan known as nibonjinron as a case study of a recurring model of nationalistic rhetoric. Focussing on an essay by the influential scholar Watanabe Schōichi, which exemplifies this hegemonic discourse of alleged uniqueness, Vitali engages on a systematic analysis of Watanabe's linguistic, stylistic and rhetorical devices. She reveals nibonjinron's dichotomic, exclusive character, its focus on primordiality, and the ideological use of language as the core and proof of this alleged uniqueness. Vitali also exposes the incoherence of the conceptualisation of this uniqueness and at the same time Watanabe's (ostensibly successful) communicative strategies.

Jennifer Meei-yau Wei (Soochow University/Taiwan) focuses on modern China/ Taiwan as a case study for investigating the intertwining of ideals of femininity and masculinity with politics, thus delivering a comprehensive view on how gender, nation and family values have been articulated in times of transitions in Taiwan in the $20^{\text {th }}$ century. Meei-yau Wei investigates the opposite ways in which the two most influential female politicians in Chinese/Taiwan modern history used gender-related argumentative strategies as well as gendered and familial metaphors to support their political agenda. She reveals how Mme. C.K.S. used family metaphors to represent the state as well as the ideal of selfless, educated "able wives and wise mothers" to support Chinese patriotism, militarism and nationalism. In contrast, Annette Lu connects her feminist argument 
against gender inequality, which she sees as a Chinese-Confucian and Japanese product, with both the issue of Taiwanese independence and global issues, such as the protection of environmental and human rights.

The papers of this issue Language.Literature.Politics. (Un)doing Nationalism and Resistance seem to agree on the perception of nationalism as a divisive, exclusivist, regressive, and anti-humanistic phenomenon. Its language, i.e. its argumentative strategies, general narratives and linguistic devices such as metaphors or neologisms, appears to be based on a friend-foe-logic that addresses and intentionally provokes negative emotions, mainly of fear, desires of homogeneity, affiliation and belonging, power, and an anxiety about an imagined common origin and unity. As to the strategy of resistance to nationalism, the contributions commonly/consistently underline the creative function of imagination as the crucial ability to go beyond existing frames of thoughts and action by thinking new 'images' as alternatives or complements to the existing frames. Thus, imagination makes it possible to question the normalised, naturalised patterns of thoughts and emotions informing nationalism itself, and to replace these patterns with others. They also stress the crucial roles of critique and (counter-)representation, and the importance of agapé, in its manifestation of compassion and solidarity. Moreover, they underline the need for counter concepts that would address not only reason and rationality, but also those "menschliche, allzu menschliche" affects and emotions which are in fact the most effective vehicles of separatist, exclusivist nationalistic ideologies themselves.

The story of the stencil on the cover image is paradigmatic of what is happening. As Thomas Hainscho (University of Klagenfurt/Austria), who photographed it in 2018, reports: This stencil portraying a woman with a headscarf and big sad eyes, was sprayed on a wall in Klagenfurt. After having being painted over with thick red spray by what appears to be xenophobic, Islamophobic individuals, it was sprayed again, only to be painted over again, and to be sprayed again. Nationalism and resistance, again and again. 